Article

\title{
Narrowing the Gap between Theory and Practice: Community of Inquiry and Its State in the Philippines
}

\section{Marella Ada V. Mancenido-Bolaños}

\begin{abstract}
This paper presents Matthew Lipman's critique of traditional pedagogy as seen in his work Thinking in Education (2003). Lipman points out that traditional pedagogy does not foster reflective thinking. This paper also discusses the historical development of the practice of community of inquiry in the Philippines from the time it was introduced by Zosimo Lee in 1996 to Manila Public Schools, and in 2012 to the teachers of Ayala Foundation, Inc. Teacher Training Institute. This article claims that Lipman's critique of traditional pedagogy mirrors the situation of Philippine classrooms. The author further argues that it is for this reason that the practice of community of inquiry still cannot be fully implemented in the country.
\end{abstract}

Keywords: Traditional pedagogy, Philosophy for Children, community of inquiry, reflective thinking

\section{Matthew Lipman's Critique of Traditional Pedagogy}

ccording to Matthew Lipman, the school is a battleground where the
future of the society is being fought. ${ }^{1}$ He adds that whereas schools
must be initiators of change, most of them remain conservative, as can be seen in the way teachers are trained in their craft. In most cases, teachers are taught to teach using manuals and textbooks. In this kind of training, their teaching ability is measured simply by their capacity to learn and memorize the manuals. Consequently, the change needed in the teaching profession cannot be initiated in the school system because of this practice.

In a democratic society, reasonableness must be inculcated in its citizens through the school system. According to Lipman, "reasonableness is \footnotetext{
2003), 9.

(C) 2018 Marella Ada V. Mancenido-Bolaños

https://www.kritike.org/journal/issue 23/mancenido-bolanos december2018.pdf

ISSN 1908-7330
}

${ }^{1}$ Matthew Lipman, Thinking in Education (New York, NY: Cambridge University Press, 
not pure rationality; it is rationality tempered by judgment." 2 This implies that schools must exert a conscious effort to treat their students reasonably. Lipman aptly says that "children educated reasonably will then translate to reasonable citizens in the future." 3

With the focus of the curriculum shifting to making students master skills useful for future employability, where do we situate reasonableness in education? Just like their teachers whose ability to teach is measured by their ability to follow the manuals, the students' capacity to think becomes equated with how much of the lessons they have memorized. Likewise, their success is then measured by the scores they get in their exams and their performance tasks. Obviously, educators must start to realize that exam and performance task scores do not necessarily equate with the students' ability to think; rather, they measure the students' ability to copy.

Lipman notes that the "pedagogical problem is, at least in its first stage, to transform the child who is already a thinking child into a child who thinks well." 4 To address this problem, there must be a program that would enable children to address such cognitive tasks and making decisions for themselves. Educational systems, which aim at teaching thinking skills to students, must consider the idea of transforming children into philosophers or decision-makers. In other words, the system must teach children to become more thoughtful, more considerate, and more reasonable individuals. ${ }^{5}$

With these, we realize that there is a need for the development of critical practice as a methodical activity in education. But in order to develop such practice, it must be distinguished from what may be referred to as the "normal practice." A normal practice can be characterized as customary, habitual, traditional, or unreflective, while a critical practice is the opposite. What is normal can be turned into a critical practice through the following: 1) criticism of the practice of one's colleagues, 2) self-criticism, 3) correction of others, and 4) self-correction. Reflection upon a practice includes inquiry into it, while an effective inquiry includes appropriate intervention. ${ }^{6}$ Indeed, a reflective paradigm assumes education to be an inquiry.

Education is an inquiry. Teachers must be able to present a problem to the students rather than immediately offer them solutions they do not understand. The reason why students are not motivated enough is because they do not experience the process of discovering the solution. Therefore, the whole process becomes less fulfilling for them.

\footnotetext{
2 Ibid., 11 .

${ }^{3}$ Ibid.

${ }^{4}$ Matthew Lipman, Fredrick Oscanyan, and Ann Margaret Sharp, Philosophy in the Classroom (Philadelphia, PA: Temple University Press, 1980), 15.

${ }^{5}$ Ibid.

${ }^{6}$ Lipman, Thinking in Education, 16-17.
}

(c) 2018 Marella Ada V. Mancenido-Bolaños https://www.kritike.org/journal/issue 23/mancenido-bolanos december2018.pdf ISSN 1908-7330 


\section{COMMUNITY OF INQUIRY IN THE PHILIPPINES}

In the second chapter of Thinking in Education, Lipman strengthens his criticism of traditional pedagogical practices. He goes on discussing how teachers resist change and how schools, in turn, refuse to take responsibility for the future of the educational system. The teachers' education program cannot just be redesigned unless they have identified clearly the aims of education. ${ }^{7}$ Lipman notes that in this case "knowledge becomes disposable," 8 so that there is no retention of knowledge, what they have learned gets easily forgotten once examinations are over. Teachers of the traditional pedagogy know that the purpose of education is to instill knowledge, and yet even this very goal is not completely achieved because of the failure of the system to create an impact on the minds of the students. There are suggestions for critical thinking; the problem, however, is that teachers insist that they have been teaching for thinking and that nothing new needs to be done. ${ }^{9}$

As discussed earlier, Lipman has made significant criticisms against the standard teaching practices of educators, specifically how they tend to resist change in the system. Teachers are not prepared to teach critical thinking and there are no efforts to engage students to think imaginatively. He stresses that "there was very little teaching for judgment"10 basically because educators do not recognize the importance of teaching it. Teachers are also not able to create a connection between critical, creative, and caring thinking. ${ }^{11}$

From these criticisms, we can glean how future teachers must be taught. Truly, educational institutions must realize the necessity of reevaluating the teacher education program as this will benefit not only future teachers but also the future of the students. Also, learning institutions must realize that it is not enough to just pass on knowledge to students; but rather, the knowledge taught to students must now enable them to critically think for themselves in the future.

With these criticisms, Lipman, together with Ann Margaret Sharp, introduced the community of inquiry as an approach to teach children critical thinking. Lipman's founding of Philosophy for Children started when he realized in the 1970s that his children's school did not give them instruction in reasoning. The problem raised by Lipman is that schools fail to teach children how to think. Thus, he introduced the idea of making children be familiar with philosophy. He noted that when philosophy is properly taught,

\footnotetext{
${ }^{7}$ Lipman, Oscanyan, and Sharp, Philosophy in the Classroom, 207.

${ }^{8}$ Lipman, Thinking in Education, 29.

${ }^{9}$ Ibid., 31.

${ }^{10}$ Ibid., 5 .

11 Ibid.
}

(C) 2018 Marella Ada V. Mancenido-Bolaños

https://www.kritike.org/journal/issue 23/mancenido-bolanos december2018.pdf ISSN 1908-7330

(c) BY-NC-ND 
it could bring a significant improvement in students' thinking. This can be done by using the community of inquiry as a pedagogy. ${ }^{12}$

Lipman's community of inquiry is rooted in Charles Sanders Peirce's scientific inquiry. The term was "broadened to include any kind of inquiry whether scientific or non-scientific." 13 It aims to convert the classroom into a community of inquiry where students listen to one another with a certain level of respect toward one another's ideas. Lipman wants to transform education into a laboratory for rationality where students learn to be reasonable so that they can grow up to be reasonable citizens, reasonable companions, reasonable parents. ${ }^{14}$ Following Hirst, he notes that all scientific knowledge is contingent and must be justified by means of evidence and reasons. ${ }^{15}$ Lipman argues that knowledge should be a finished product of the inquiry process, it is logically organized in such a way that facts supported with evidence, and opinions are accompanied by reason and judgments are made with relevant criteria. He also uses Hirst's theory of thinking in the discipline where when a student is taught history, he must be able to think historically. ${ }^{16}$ Moreover, community of inquiry is also a process which has a sense of direction, that is, it moves where the argument takes it; it is dialogical. ${ }^{17}$ In such situations, we must see the teacher as the one who mediates and not the one who dominates the discussions. ${ }^{18}$ In this approach, we do not run the risk of indoctrinating students because the students are the ones who deliver the discussions based on their experiences and perspectives.

It is important to note that Lipman is aware of the present dilemma of educators. He knows that teachers are not given the free hand on how and what to teach their students because these are matters which are already decided on by school districts. On the other hand, he observes that children in kindergarten are curious, lively, imaginative, and inquisitive. These qualities dwindle as they age especially when these philosopher-like qualities are not nurtured. As a consequence, children eventually perceive only the social aspect of the school and forget about the educational aspect. ${ }^{19}$ Their enthusiasm for learning is not sustained because of the rigidity of the structured learning process. In the current system, we see how classroom discussions are focused on factual details. Students are being numerically graded through their scores in the examination which does not actually speak of how much they have learned but of how much they remember. On this

\footnotetext{
12 Ibid., 3-4.

${ }^{13} \mathrm{Ibid}, 20$.

${ }^{14}$ Ibid., 22.

${ }^{15}$ Ibid.

${ }^{16}$ Ibid., 24.

${ }^{17}$ Ibid., 83.

${ }^{18}$ Ibid., 84.

${ }^{19}$ Ibid., 12.
}

(c) 2018 Marella Ada V. Mancenido-Bolaños https://www.kritike.org/journal/issue 23/mancenido-bolanos december2018.pdf ISSN 1908-7330 


\section{COMMUNITY OF INQUIRY IN THE PHILIPPINES}

note, Van der Leeuw suggests, as quoted by Vansieleghem and Kennedy, that "reflection and reasoning cannot be realized when we only reserve separate hours a week for collective exploration of philosophical questions." 20

One might ask: If traditional schools are not open to the idea of transforming itself into becoming a more reflective and inquiry-based education system, is it possible to form communities of inquiry without transforming the whole education system?

David Kennedy suggests that this could or could not work, considering that there might be inconsistencies between what is being taught in the classroom of a community of inquiry and the traditional classroom setting which could confuse students. Yet, it could work because "wherever the community of inquiry actually forms, it will through its very operation work to transform its setting from transmission to dialogical." ${ }^{21}$ However, Kennedy recognizes that this is a weak proposition because if teachers cannot show how it relates to other aspects of school work, either the classroom will reject it or the scheme will simply not work. ${ }^{22}$ With this, we realize that there is really a need to transform the entire system into a community of inquiry, otherwise participants will not see its relevance and the system will not be able to instigate the change it wants.

While it is essential to learn the theories behind the facilitation of the community of inquiry, it is equally important to learn how to put it into practice. Transforming the system may be a necessity, but this transformation must begin with the teachers who are willing to take on the challenge. The next part of this paper will show how theory can be set into practice.

\section{Narrowing the Gap between Theory and Practice}

The new curriculum for preservice teacher education encourages deep and complex knowledge which emphasizes, according to Bernardo, the "acquisition and cognitive processing of more conceptual, theoretical, and abstract forms of knowledge ..., [stressing] the importance of understanding how knowledge and skills are contextualized or are meaningful in specific problem situations or context of inquiry." ${ }^{23}$ Bernardo suggests that teachers

\footnotetext{
${ }^{20}$ Nancy Vansieleghem and David Kennedy, "What is Philosophy for Children, What is Philosophy with Children-After Matthew Lipman?" Journal of Philosophy of Education, 45:2 (2011), 178

${ }^{21}$ David Kennedy, "The Community of Inquiry and Educational Structure," in Thinking Children and Education, ed. by Matthew Lipman (Dubuque, IA: Kendall/ Hunt Publishing Company, 1993), 356.

22 Ibid.

${ }^{23}$ Allan B.I. Bernardo, "Learning about Learning: Cognitive Processing Constraints in Teacher Educators Developing New Understanding about Learning and Pedagogy and How to
} 
must have an appreciation for the theories of knowledge and the technical strategies to be used in addressing specific aspects of learning.

Cognitive and metacognitive factors in learning are also included in the new curriculum. This dimension of learning is focused on the role of metacognitive process or, in other words, reflecting about thinking, in education. It is also concerned with eliciting the students' prior knowledge to enable the teacher to bridge the gap between what the students already know and what is yet to be learned.

It is noticeable that these new courses in the preservice teacher's curriculum are highly philosophical in nature. We read terms such as cognition, reflection, critical thinking, and nature of knowledge. Yet, when we review the actual curriculum of preservice teachers in the country, courses, such as Philosophy of Education or Epistemology, are absent. This is true even in the top-ranking colleges of education.

Instead of Philosophy of Education and Epistemology, the College of Education of the University of Santo Tomas offers History and Philosophy of Science to science majors and Philosophical and Ethical Foundations of Values Education to religious education majors. It is interesting to note that these two courses are not assigned to the Department of Philosophy. They have courses which are supposed to be philosophical in nature, such as Principles of Teaching I and II, which include the foundations of the discipline, as well as Facilitating Learning, which teaches contemporary theories and researches on the "cognitive, metacognitive, motivational, sociocultural, and individual difference factors in the acquisition of learning." 24 Both of these courses have a common prerequisite: Psychology 1.25

In addition, they offer Scientific Reasoning and Critical Thinking, which is "a study of the methodological components of the social sciences as tools to explain certain phenomena in the understanding of logical reasoning and critical thinking." 26 Finally, there is a Seminar in Education, which discusses the historical, legal, and philosophical foundations of education.

Unfortunately, the only subjects assigned to the Department of Philosophy are Logic and Professional Deontology. This seems anomalous if we consider assigning subjects to those who are equipped to teach courses according to their academic preparation and research. The presence of the term "thinking" in a course title does not immediately warrant that it belongs to psychology. Nor is the term social science exclusive to sociological theory.

Overcome Them," in Ripples of Change: A Journey of Teacher Education Reform in the Philippines (Quezon City: Commission of Higher Education, 2007), 60.

${ }^{24}$ University of Santo Tomas College of Education Course Prospectus (Manila, 2005), $72-94$.

${ }^{25}$ Ibid., 60-61.

${ }^{26}$ Ibid., 101.

(c) 2018 Marella Ada V. Mancenido-Bolaños https://www.kritike.org/journal/issue 23/mancenido-bolanos december2018.pdf ISSN 1908-7330 


\section{COMMUNITY OF INQUIRY IN THE PHILIPPINES}

The foundations or underlying theories of different fields and concepts are philosophical and could be appropriately handled only by the teachers who have the specific preparation for them.

The University of the Philippines does not offer the course Philosophy of Education in the undergraduate program; instead, they have Educational Thought and Practice. In the graduate level, however, they offer Philosophy of Education, Psycho-Philosophical Foundations of Education, Philosophy of Curriculum, and Seminars in Philosophy of Philippine Education, which are being taught by professors equipped to handle the course. ${ }^{27}$

These being said, we cannot expect teachers to efficiently teach reflective thinking to their students because of their lack of training and experience. It would be a challenge to bring Lipman's thoughts into Philippine classrooms precisely because teachers are not fully equipped to take on the task. This is evidenced by the work done by Zosimo Lee.

\section{The State of Community of Inquiry in the Philippines}

Zosimo Lee introduced the practice of reflective thinking in the elementary classrooms and Philosophy for Children after he had attended the Mendham workshop of the Institute for the Advancement of Philosophy for Children (IAPC) in 1996 and in 2000.28 From 1992 to 1996, the faculty members of the Department of Philosophy of the University of the Philippines Diliman were giving lectures on Logic, Epistemology, Metaphysics, and Ethics to the teachers of public schools in Manila, who had initially found philosophy "intimidating and esoteric." 29 This endeavor did not lead immediately to any concrete outcome. In 1996, through the initiative of Dr. Paraluman Giron, the contact was reestablished and the trainings resumed. There were lecture discussions on critical and creative thinking. The teachers proved to be receptive to the ideas because it was at this time that the higher-order thinking was introduced as a requirement in the schools for basic and secondary education. In particular, the teachers of English were the most receptive because they immediately saw the usefulness of the program. They claimed to have been using the pedagogy but did not have the vocabulary for their practice. ${ }^{30}$ Since the concept of higher-order thinking was

\footnotetext{
27 "Academic Programs," in Office of the University Registrar, University of the Philippines, Diliman,http://our.upd.edu.ph/acadprog.php?fbclid=IwAR1LENgmJE8n7g5OyveVvbjof7dxAo pflV5oTXkFdQMPzfy4jibFCgi8KM8.

28 See Zosimo Lee, "Philosophy for Children in the Philippines," in Children Philosophize Worldwide: Theoretical and Practical Concepts, ed. Eva Marshal, Takara Dobashi, and Barbara Weber (Frankfurt: Peter Lang, 2009).

${ }^{29}$ Ibid., 2.

${ }^{30}$ Ibid.
}

(c) 2018 Marella Ada V. Mancenido-Bolaños

https://www.kritike.org/journal/issue 23/mancenido-bolanos december2018.pdf ISSN 1908-7330

(cc) BY-NC-ND 
already introduced to them by the Department of Education (DepEd), they were interested to acquire the skills so they could eventually teach it to their students. The eager teachers realized that "schooling is not always educating, and that educating has to involve enabling their students to become better thinkers." 31 Some of them became critical of their own practice and started to evaluate its philosophical underpinnings. The challenge was that, although the teachers were receptive of the practice, they could not immediately use it in the classroom because of the bureaucracy in their respective schools. Some of them even became "wary of the new techniques and method," reverting back to the feeling that what they were doing was sufficient enough and that there was no need to change or modify it. ${ }^{32}$

Nonetheless, Lee and the other members of the department continued to train public school teachers in Manila for the next two years. The group conducted workshops and regular meetings with teachers in many elementary and secondary schools in Manila. Groups of 25 teachers each began conducting weekly sessions at the Juan Luna Elementary School. For two years the group was able to train 200 teachers, around 35 of whom were convinced to take the second level of further training. Lee noted that "the discussion progressed and certain important debates took place." ${ }^{33}$

The challenge in this program came when the teachers, who were asked to work on their own materials, were not able to comply with the requirement. Lee noted that the teachers might not have learned enough to feel confident about their own work, or they found the task to be difficult. "There was a problem of transfer," Lee said, "in that sense the thinking skills program was not very successful." 34

Moreover, the two-year program was not documented and assessed, and there was no measure to check the impact the "intervention would have on the students." 35 However, in a paper presented by Nancy Sta. Ana, she noted that in 1993 to 1995 :

Statistical data on tests in reasoning and critical thinking before and after using the community of inquiry yielded from $5 \%$ to $12 \%$ increase in scores of pupils. The reasoning/critical thinking test was provided by PNU and was conducted by academic supervisors of English,

\footnotetext{
${ }^{31}$ Ibid.

32 Ibid., 3.

${ }^{33}$ Ibid., 4.

${ }^{34}$ Ibid.

${ }^{35}$ Ibid.
} 
Filipino, and Hekasi supervisors at the beginning and the end of two consecutive school years. ${ }^{36}$

Sta. Ana added that the community of inquiry approach was continuously used by teachers in their language classes, "either as a part of their Reading lessons or as a separate Friday lessons on Philosophy." ${ }^{37}$ At the time of her presentation, she stressed that there were challenges in the implementation of the program. However, she suggested that there may be practical solutions, such as, "teacher mentoring, immersion through guided practice as a participant in a community of inquiry, collaborative partnership with experts, supervised implementation in the teacher's classroom, participation in support system to discuss experiences and pooling of educational resources and materials." 38

Sta. Ana commended the commitment of the practitioners to the program, and to support her claim, she mentioned the achievement of Jesusa Antiquierra of P. Gomez Elementary School who was selected as one of Metrobank's Outstanding Teachers of the Philippines. Antiquierra used the community of inquiry approach in her classes. The award-giving body praised her work saying: "her impact on children is remarkable. Her pupils become an engaging group of reflective, creative, and critical thinkers and philosophers who can identify good reasons, make distinctions and connections, formulate and answer probing questions." 39

Lee, in another article, mentioned that in 2013 there was a renewed interest in the program because of the current shift of the Philippine educational system to K-12. In April 2013, a seminar with Manila public school teachers was conducted and the teachers were immediately convinced that "they should provide this opportunity for their children to develop communities of inquiry." 40

Lee discussed several challenges in the implementation of Philosophy for Children, or P4C, in the Philippines, as follows:

1. Implementation of thinking skill and reflective inquiry program in colleges of education

2. Best practices, models, and paradigms of schools using the Philosophy for Children

\footnotetext{
${ }^{36}$ Nancy Sta. Ana, "P4C: The UP-DepEd Manila Story" (paper presented at the Karunungan Festival 2, O.B. Montessori, Inc., Greenhills, San Juan, 29-30 August 2008).

37 Ibid.

${ }^{38}$ Ibid., 3.

${ }^{39}$ Ibid.

40 Zosimo Lee, "Nurturing Communities of Inquiry in the Philippine Schools," Thinking: The Journal of Philosophy for Children, 20:3-4 (2014), 80.

(c) 2018 Marella Ada V. Mancenido-Bolaños https://www.kritike.org/journal/issue 23/mancenido-bolanos december2018.pdf ISSN 1908-7330
}

(c) BY-NC-ND 
3. Developing instructional materials

4. Training public school teachers in facilitating philosophical dialogue. ${ }^{41}$

As shown earlier, if the curriculum does not foster or cater to the development of thinking skills and reflective inquiry, it would be difficult for teachers to act as models of reflective thinkers since they themselves would not know how to be reflective. In Elicor's recently published article, he notes that "teachers who utilize COI as a pedagogy cannot exercise a hierarchical relation between their intelligence and that of the students." 42 He adds that the teacher must also be open to an intellectual journey with their students and allow himself/herself to be taught, thus, he/she must prod his/her students to dig deeper. ${ }^{43}$ In a way, the teacher must be able to learn and appreciate the shifting of his/her role from being the conveyor of knowledge to being a facilitator of the discussion. Further, the teachers must also be willing to learn from the best practices of the international community of $\mathrm{P} 4 \mathrm{C}$ scholars and practitioners because these could enable them to improve their craft.

Similarly, Kennedy noted that one way of preparing teachers to teach philosophy to children is by making them evaluate their own beliefs and understanding of childhood and the philosophy of childhood. Through this, teachers will gain an understanding of the adult-child relationship which is essential in building a community of inquiry. He also adds that teachers themselves should be engaging in "CPI with each other on an on-going basis, and devoting that inquiry or at least one major dimension of it-specifically to philosophy of childhood." 44

He argues that in understanding childhood, teachers may come across other thoughts which are related to childhood; topics on the human person, human nature, history, literature, technology, and psychology might be brought to fore. Through this kind of critical inquiry teachers are able to "challenge stereotypes and habitual interpretative misunderstanding of children's motives and understanding." 45 Thus, teachers understand the children better and, in the process of engaging with the children, they also realize that some children are doing it better than before, that the children's ear is already becoming more philosophical. ${ }^{46}$ For Kennedy, the teacher's

\footnotetext{
${ }^{41}$ Ibid.

42 Peter Paul E. Elicor, "The Notion of Pedagogical Authority in the Community of Inquiry," Kritike: An Online Journal of Philosophy, 11:2 (December 2017), 90.

${ }^{43}$ Ibid.

44 David Kennedy, "Practicing Philosophy of Childhood: Teaching in the (R)evolutionary Mode", Journal of Philosophy in Schools, 2:1 (2015), 11-14.

${ }^{45}$ Ibid., 9.

${ }^{46}$ Ibid.
}

(c) 2018 Marella Ada V. Mancenido-Bolaños https://www.kritike.org/journal/issue 23/mancenido-bolanos december2018.pdf ISSN 1908-7330 


\section{COMMUNITY OF INQUIRY IN THE PHILIPPINES}

understanding of childhood and the process of CPI (i.e., community of philosophical inquiry) play an important role in the program. Until teachers see the importance and use of CPI, they will not be able to carry on with the program successfully.

Lee argued that the premier schools in the country may have the best facilities and equipment, as well as the most updated collection of books, but the fact remains that the academic practice continues to be unreflective. Teachers still understand teaching as a mere transmission of knowledge without effecting reflection among students. The prevailing method still does not transform students to become active and reflective thinkers. Lee also emphasized that one problem of $\mathrm{P} 4 \mathrm{C}$ in the country is the lack of reading materials. He thinks that students cannot just use Lipman's novels and the other IAPC materials because of their cultural content. Students cannot immediately relate to the texts because the stories are not a part of their worldview. ${ }^{47}$

The development of manuals is important because this is the primary material that can be used to stimulate a community of inquiry. Glenda Oris, another advocate of Philosophy for Children, answered to this call. She has authored a number of children's books, such as Looking out for Heroes; Kwento ng Isang Mambabasa (A Reader's Story); Whuush!; Ang Madyik ni Paolo; Ayun, O! Handaan; Ayun, O! Surpresa; Ayun, O! Laro Tayo!; Ayun, O! Bakasyon na!; and Ayun, O! Pasukan na! In her presentations, Oris makes use of her books as stimulus for a community of inquiry. Her involvement in the program started when she was invited to present a paper during the 15th International Council of Philosophical Inquiry with Children (ICPIC) Conference held in Jinju, South Korea, in July 2011. After the said conference she became one of the two representatives for the Philippines; the other one is Rainier Ibana, who is currently the President of Philosophy for Children and Youth Network for Asia and the Pacific. Since then, she has become a regular speaker in the UNESCO-sponsored conferences organized annually by Ibana and his team.

Looking at the possible contribution of Filipino philosophers to the program, Lee says, "[T]hey can provide intellectual ramparts and guidance that will allow such a process to reach maturity and fruition." 48 Filipino philosophers must look at the program as an opportunity to help in transforming the conduct of classes by making it reconstructive and reflective. This initiative must spring from an authentic desire and the sincerity to support students and teachers who are just learning how to conduct a community of inquiry. Training public school teachers to facilitate

\footnotetext{
${ }^{47}$ Lee, "Philosophy for Children in the Philippines," 15.

${ }^{48}$ Lee, "Philosophy for Children in the Philippines," 9.
} 
a philosophical dialogue is a challenging task inasmuch as a number of them tend to resist the new method and question its efficiency, insisting that the old practice is just as good.

To date, there is a growing number of Filipino philosophers who are willing to take part in training in-service teachers to do reflective thinking in their respective classes. Abigail Thea Canuto of the University of the Philippines wrote her thesis on "Critical Thinking and 'Philosophical Progress' in Dialogues of Grade Two Children in a Community of Inquiry." 49 She also handles philosophy courses at the UP College of Education where she uses the community of inquiry as a pedagogy. Rowena Azada-Palacios started training with Society for the Advancement of Philosophical Enquiry and Reflection in Education (SAPERE) in 2015. She attended trainings in the UK, Singapore, and Korea and already completed the SAPERE level 3 training. To date, she has trained approximately 400 teachers, some have utilized the community of inquiry in their classes. Moreover, she also uses the community of inquiry in her philosophy classes at the Ateneo de Manila University and according to her, she has students from the teacher education program who were able to utilize it in their respective classes as well.

Maria Lovelyn Corpuz-Paclibar and Mark Joseph Calano from Ateneo de Manila University were also able to train with Philosophy with Children and Youth Network for Asia and the Pacific in 2015, and Peter Paul Elicor of Ateneo de Davao University in 2017. Leander Marquez and Cathryne Joy Alvarez of the University of the Philippines, and Marella Ada Mancenido-Bolaños of the University of Santo Tomas attended the 2017 Residential Workshop with the IAPC in Mendham, New Jersey.

Marquez and Alvarez handle the National Service Training Program of the University of the Philippines. In this program, they train college students to facilitate a community of inquiry during the first semester in preparation for their 45-hour community engagement during the second semester at the San Vicente Elementary School in Diliman, Quezon City. Marquez notes that the administrators, teachers, and students of San Vicente Elementary school are very receptive to the practice, and the principal is even willing to enter into a contract with them for the continuity of the said program. ${ }^{50}$

Peter Paul Elicor of Ateneo de Davao University facilitates classes with some indigenous ethnic groups and other marginalized students in Mindanao. Meanwhile, Marella Mancenido-Bolaños, together with Fleurdeliz Altez-Albela and the undergraduate philosophy students of the

49 Abigail Thea O. Canuto, “Critical Thinking and 'Philosophical Progress' in Dialogues of Grade Two Children in a Community of Inquiry" (M.A. Thesis, University of the Philippines, April 2013).

${ }^{50}$ Leander Marquez, correspondence with author, August 2018.

(c) 2018 Marella Ada V. Mancenido-Bolaños https://www.kritike.org/journal/issue 23/mancenido-bolanos december2018.pdf ISSN 1908-7330 


\section{COMMUNITY OF INQUIRY IN THE PHILIPPINES}

University of Santo Tomas, facilitates community of inquiry classes with the alternative learning system students of Juan Luna Elementary School.

The community of inquiry is consistently used by teachers from Ayala Foundation, Inc.'s partner schools. Teachers are continuously trained and monitored by the foundation to ensure that they are able properly utilizing the practice in their respective classes.

\section{Putting Theory into Practice: Community of Inquiry in CENTEX Schools}

In 2012, Lee introduced Philosophy for Children to the Center of Excellence in Public Elementary Education (CENTEX) through the initiative of Ayala Foundation, Inc. (AFI). The outcome of the workshop is the foundation's implementation of the community of inquiry in their partner schools, particularly CENTEX Manila and Batangas. ${ }^{51}$ CENTEX operates in Tondo, Manila and Bauan, Batangas. This project, which is a partnership between DepEd and AFI, started operating in 1998, and since then 634 students have graduated from both schools. ${ }^{52}$

During several meetings and school visits, the author was able to observe an actual COI (community of inquiry) session in CENTEX Manila. The author was able to observe four classes that consistently used the community of inquiry in the conduct of their lessons: Kindergarten, Grade 1, Grade 2, and Grade 5. The author was also able to interview the teachers of these respective classes and selected $5^{\text {th }}$ graders who have been immersed in the program for the longest time.

The conversations with the $5^{\text {th }}$ graders revealed that they liked the program. They emphasized that it changed their views about learning because they had realized that there could be a better way of learning. They appreciated the fact that in the COI there are no definite answers, and everyone can speak their minds without fear of being judged by their classmates. They liked the fact that friendship grew in their class because they eventually learned about the background of their classmates. Students who were able to understand the lesson faster helped the others to understand the more difficult topics. The discussions were not focused only on the more intelligent students in the class, because even the slow learners are given the opportunity to speak.

According to Student A, the community of inquiry changed his view about learning. He realized that "there's something more than being on top of this school ... with the community of inquiry, I feel like I have more

\footnotetext{
51 "CENTEX," in Ayala Foundation

http://www.ayalafoundation.org/program/centex/.

52 Ibid.

(C) 2018 Marella Ada V. Mancenido-Bolaños

https://www.kritike.org/journal/issue 23/mancenido-bolanos december2018.pdf

ISSN 1908-7330
}

(c) $)$ BY-NC-ND 
freedom to express what I want ... you can say that in a community of inquiry, there is no right or wrong answer because it is their opinion." Meanwhile, Student B notes that learning has become more interesting since they started using COI in their class.

The teachers interviewed were very receptive to the program. They are convinced that the community of inquiry has changed their perspective on teaching. According to a grade 5 teacher, in the traditional method, the questions would usually come from her in an effort to help the children understand the topic being discussed. Through COI, however, she realized that children have "varied ideas, if you just allow them to express what they think .... That is, when they learn to be very expressive and articulate on what their thoughts are." She added that the program helped in the development of the children's critical thinking, and that the students were able to develop concepts analytically. She noted that when she was still using the traditional method of providing questions to the students, the discussions were shallow because the class was not able to thoroughly explore the topics; but when she began using COI in her classes, she noticed that the children's line of questioning became critical such that they would now know how to put themselves in the place of the characters in the story.

The author had the chance to observe the conduct of her class and noticed that there were students who were able to facilitate their group. The student facilitators were already able to classify the questions, asking the members of the group which questions were to be addressed first. The students were able to synthesize the discussions and challenge one another's ideas. There were even instances when the children resorted to using the COI even outside the classroom.

The $5^{\text {th }}$ grade teacher recommends that the practice be a continuous one. According to her, if it has been introduced to kindergartners in their English class, it should be possible also to use it in the other subject areas, such as science and math. It should also be practiced at each year level to maximize learning. One of the problems they encountered, however, is that the pedagogy is sometimes used by a teacher in a particular year level, but when the students reach the next year level the new teacher opts for a different method in her class. There is no continuity in the process, thus, they are not able to maximize the development of the students' thinking skills.

With the discussions cited above, it is evident that the students are able realize their ability to generate knowledge. The interview with the students is proof that the students trusted the whole process, they know that they are building on one another's ideas and that they are learning from one another.

In 2017, preschool teachers from Jacinto Zamora Elementary School were also able to bring the practice to their school. AFI recommends that this

(c) 2018 Marella Ada V. Mancenido-Bolaños https://www.kritike.org/journal/issue 23/mancenido-bolanos december2018.pdf ISSN 1908-7330 


\section{COMMUNITY OF INQUIRY IN THE PHILIPPINES}

group of preschool teachers be allowed to teach in first grade during the next academic year to be able to handle the same class they handled during this academic year. This would allow the teachers to follow up on the students' progress.

In a conversation with the AFI's project coordinators, they cited several problems that they encounter in the implementation of the program. They noted that teachers tend to be consumed by the objectives set in their lesson plans as mandated by DepEd that they feel the urge to accomplish it rather than focus on the proper delivery of COI in their respective classes. They were also having difficulty in convincing DepEd to, once and for all, consider P4C training as a valid training that could be credited. The foundation wishes to develop the program further by looking into indicators of success for both teachers and students. They wanted to come up with a measure or rubric for this, because such an instrument can help them convince DepEd to adopt the CENTEX model. Lastly, they want to apply with National Educators Academy of the Philippines (NEAP) for the validation of the Training Institute curriculum and the accreditation of their training hours so that teachers will be encouraged to attend the training and eventually implement the program in the classroom.

\section{Conclusion}

There is still a difficulty in implementing the program in the Philippines as discussed by Lee in his articles. However, there is a consistent growth in the number of scholars who are willing to train basic education teachers and work with public school teachers in implementing the program. There is also a growth in the number of teachers who are convinced to use the pedagogy in their respective classes. The democratic practice in the Philippine educational system where priorities of the DepEd shifts every time a new president is elected contributes to the difficulty in implementing the program. In addition, the priorities set by Division Heads is also an issue. DepEd still adheres to the traditional method of knowledge transfer from teacher to student and is still resistant to new methods.

With the introduction of outcomes-based learning in the country where students are required to produce tangible projects as part of their performance tasks, the idea of allowing students to engage in a community of inquiry in class becomes unimaginable as teachers are not trained to have an ear for philosophical discussions that might ensue in class. According to the Department of Education (February 2018), in Metro Manila alone, there are 517 public elementary schools, 247 public secondary schools, 1,495 private preschools, 1,304 private elementary schools, and 820 private secondary schools that cater to two million students in the region. To be able to convince 
the Division Head to train the teachers in the region and to finally implement it in their classes is a big challenge.

Lipman, Oscanyan, and Sharp in Philosophy in the Classroom (1980), notes that people are predisposed to think that the problem lies in the fact that "many children today are bored and apathetic, and that this is a direct result of their home environment." 53 However, they argue that no matter how little children are stimulated at home, when they enter kindergarten they are curious and very eager to learn. When they reach their third grade, their inquisitiveness starts to dissipate and, by the time they reach middle school, they feel simply compelled to stay in school. Lipman suggests that schools must help children find meanings relevant to their lives. Schools must be able to establish opportunities which will enable children to sustain their curiosity. Teachers may once again argue that they are already doing this in their classrooms. Lipman insists that children must be taught to think as thinking enables us to acquire meaning. ${ }^{54}$

One of the reasons why students are not trained to think reflectively is because even their teachers have not been trained to do reflective thinking. As a result, they lack the creativity to stimulate the minds of the students. Says Lipman, "The problem of method in forming habits of reflective thought is the problem of establishing conditions that will arouse and guide curiosity; of setting up connections in the things experienced that will on later occasions promote flow of suggestions, create problems and purposes that will favor consecutiveness in the succession of ideas." 55

It is clearer now that there is a need to revisit the teacher education curriculum in the Philippines. As long as we do not change the way we look at how teachers are being trained, the case will remain the same. We cannot expect teachers to change their practice unless they have been well-grounded in theory and in reflective, inquiry-based practice. It is when they are able to understand the philosophy behind each pedagogical method will they be able to gain full appreciation of the practice.

Department of Philosophy, University of Santo Tomas, Philippines

\section{References}

Bernardo, Allan B.I., “Learning about Learning: Cognitive Processing Constraints in Teacher Educators Developing New Understanding about Learning and Pedagogy and How to Overcome Them," in

\footnotetext{
${ }^{53}$ Lipman, Oscanyan, and Sharp, Philosophy in the Classroom, 12.

54 Ibid., 12-13.

${ }^{55}$ Lipman, Thinking in Education, 2.
}

(c) 2018 Marella Ada V. Mancenido-Bolaños https://www.kritike.org/journal/issue 23/mancenido-bolanos december2018.pdf ISSN 1908-7330 
156 COMMUNITY OF INQUIRY IN THE PHILIPPINES

Ripples of Change: A Journey of Teacher Education Reform in the Philippines (Quezon City: Commission of Higher Education, 2007).

Canuto, Abigail Thea O., "Critical Thinking and 'Philosophical Progress' in Dialogues of Grade Two Children in a Community of Inquiry," (M.A. Thesis, University of the Philippines, April 2013).

"Values Education for a Democratic Society" (paper presented during the Seminar/Workshop on Values Education, Philosophy of the Human Person, Media Values and Society in the K-12 and Senior High School Context, University of the Philippines, Diliman, Quezon City, 3 December 2016).

"CENTEX," in Ayala Foundation http://www.ayalafoundation.org/program/centex/.

Elicor, Peter Paul E, "The Notion of Pedagogical Authority in the Community of Inquiry," Kritike: An Online Journal of Philosophy, 11:2 (2017).

Kennedy, David, "Practicing Philosophy of Childhood: Teaching in the (R)evolutionary Mode," Journal of Philosophy in Schools, 2:1 (2015).

"The Community of Inquiry and Educational Structure," in Thinking Children and Education, ed. by Matthew Lipman (Dubuque, IA: Kendall/ Hunt Publishing Company, 1993).

Lee, Zosimo, "Nurturing Communities of Inquiry in the Philippine Schools," Thinking: The Journal of Philosophy for Children, 20:3-4 (2014).

"Philosophy for Children in the Philippines," in Children Philosophize Worldwide: Theoretical and Practical Concepts, ed. by Eva Marshal, Takara Dobashi, Barbara Weber (Frankfurt: Peter Lang, 2009).

Lipman, Matthew, Lisa (New Jersey: Institute for the Advancement of Philosophy for Children, 1983).

Philosophy Goes to School (Philadelphia: Temple University Press, 1988).

Thinking in Education (New York, NY: Cambridge University Press, 2003).

Lipman, Matthew, Fredrick Oscanyan, and Ann Margaret Sharp, Philosophy in the Classroom (Philadelphia, PA: Temple University Press, 1980).

Payongayong, Ma. Theresa T., "Creating a Community of Inquiry through Philosophy," Transactions of the National Academy of Science and Technology Philippines, 29 (2007).

Sta. Ana, Nancy, "P4C: The UP-DepEd Manila Story," (paper presented at the Karunungan Festival 2, O.B. Montessori, Inc., Greenhills, San Juan, 2930 August 2008).

Vansieleghem, Nancy and David Kennedy, "What is Philosophy for Children, What is Philosophy with Children-After Matthew Lipman?" Journal of Philosophy of Education, 45:2 (2011).

(C) 2018 Marella Ada V. Mancenido-Bolaños

https://www.kritike.org/journal/issue 23/mancenido-bolanos december2018.pdf

ISSN 1908-7330

(cc) BY-NC-ND 